\title{
Spinal cord stimulator for the treatment of ischemic pain-Burger's disease and Raynaud's disease: A report of two cases and literature review
}

\author{
İskemik ağrı-Burger hastalığı ve Raynaud hastalığı tedavisinde spinal kord stimülatörü \\ uygulaması: 2 olgu sunumu ve literatür taraması
}

(D) Esra ERTILAV, 1 (D) Osman Nuri AYDIN²

\begin{abstract}
Summary
Ischemic pain is the main symptom of a group of diseases that result in inadequate blood flow to the extremities and ischemia. In this symptomatology, two major diseases are distinguished: Critical vascular disease and Raynaud's phenomenon. Critical vascular disease background of atherosclerosis caused by diabetes mellitus or hypertension. Raynaud phenomenon is divided into primary and secondary form. The primary form is due to vasospasm and there is no underlying cause. Secondary form is associated with underlying connective tissue or rheumatic diseases, peripheral vascular diseases such as thromboangitis obliterans (Burger's disease). Clinical findings in Raynaud's disease are vasomotor changes with cold exposure such as bruising, coldness, painful paresthesias, and ulcers due to chronic ischemia. Clinic presentation in critical ischemic disease is intermittent claudication for earlier stage and resting pain, gangrene, necrosis, and trophic changes were added in advanced stages. The treatment of the Raynaud's disease in early stage is medical and conservative. In case of advanced stage ischemic vascular disease, medical treatment resistant pain, insufficient response to endovascular treatment, and inoperabl cases, interventions such as sympathectomy and spinal cord stimulation (SCS) can be applicable. SCS reduces vascular resistance through vasodilator mediators and increases blood flow. SCS also suppresses sympathetic vasoconstriction, increases tissue vascularity, reduces tissue damage, provides ulcer healing and pain reduction. In this report, we demonstrated that persistent Raynaud's disease and advanced stage Burger's disease were successfully treated with SCS.
\end{abstract}

Keywords: Burger's disease; ischemic pain; Raynaud's disease; spinal cord stimulator.

\begin{abstract}
Özet
İskemik ağrı, ekstremitelere yetersiz kan akımıyla sonuçlanan bir grup hastalığın ana semptomudur. Bu semptomatolojide iki ana hastalık ayırt edilir: Kritik vasküler hastalık ve Raynaud fenomeni. Kritik vasküler hastalık diabetes mellitus veya hipertansiyonun neden olduğu aterosklerozun zemininde gelişmektedir. Raynaud fenomeni primer ve sekonder forma ayrılır. Primer form vazospazmdan nedenlidir ve altta yatan bir neden yoktur. İkincil form, altta yatan bağ dokusu veya romatizmal hastalıklar, tromboanjitis obliterans (Burger hastalığı) gibi periferal vasküler hastalıklarla ilişkilidir. Raynaud hastalığında klinik bulgular, soğuğa maruz kalma ile morarma, soğukluk, ağrılı parestezi gibi vazomotor değişiklikler ve kronik iskemiden kaynaklanan ülserlerdir. Kritik iskemik hastalıkta klinik prezentasyon, erken evre için intermittan kladikasyo ve ileri evrelerde istirahat ağıısı, kangren, nekroz ve trofik değişiklikler de eklenir. Raynaud hastalığının erken evrede tedavisi medikal ve konservatiftir. İleri evre iskemik vasküler hastalık, tıbbi tedaviye dirençli ağrı, endovasküler tedaviye yetersiz yanıt, inoperabl olgular gibi durumlarda sempatektomi ve spinal kord stimülasyonu gibi girişimler uygulanabilir. Spinal kord stimülasyonu vazodilatör mediyatörler ile vasküler direnci azaltır ve kan akımını artırır. Spinal kord stimülasyonu ayrıca sempatik vazokonstrüksiyonu baskılar, doku kanlanmasını artırır, doku hasarını azaltır, ülser iyileşmesini sağlar ve ağrıyı azaltır. Bu olgu sunumunda dirençli Raynaud hastalığının ve ileri evre Burger hastalığının spinal kord stimülasyonu ile başarılı bir şekilde tedavi edildiği gösterildi.
\end{abstract}

Anahtar sözcükler: Burger hastalığı; iskemik ağrı; Raynaud hastalığı; spinal kord stimülatörü.

'Division of Algology, Department of Neurology, Adnan Menderes University Faculty of Medicine, Aydın, Türkiye ${ }^{2}$ Division of Algology, Department of Anesthesiology and Reanimation, Adnan Menderes University Faculty of Medicine, Aydın, Türkiye

Submitted (Başvuru): 08.10.2019 Revised (Revizyon): 08.03.2020 Accepted (Kabul): 12.03.2020 Available online (Online yayımlanma): 23.07.2020

Correspondence: Dr. Esra Ertilav. Adnan Menderes Üniversitesi Tıp Fakültesi, Nöroloji Anabilim Dalı, Algoloji Bilim Dalı, Türkiye. 


\section{Introduction}

Critical vascular disease is common in patients older than 55 years due to arterial vascular disease developing at the backdrop of atherosclerosis. ${ }^{[1]}$

Raynaud's phenomenon is examined under primary and secondary form, ${ }^{[2]}$ and its primary form (Raynaud's disease) is idiopathic vasospastic disorder that occurs without apparent cause and with good prognosis. ${ }^{[3]}$ The secondary form (Raynaud's syndrome) seen with connective tissue and rheumatic disease (scleroderma, sjogren's disease, rheumatoid arthritis, systemic lupus erythematosus, and polymyositis), peripheral vascular disease (thromboangitis obliterans-Buerger's disease), ${ }^{[4]}$ malignancy, or chemotherapy (such as cisplatin, bleomycin). ${ }^{[5]}$ Pathophysiology of Raynaud's disease is still unclear, increased physiological vasoconstriction in the cold with increased sensitivity to a2-agonists and serotonin are accused. Vasoconstrictive endothelin-1, calcitonin gene related peptide (CGRP), and cyclooxygenase play a modulating role. ${ }^{[6]}$

Clinical symptoms in critical vascular disease begin with intermittent claudication, in advanced stages resting pain, gangrene, necrosis, and trophic changes were added. Raynaud phenomenon presented with pain, paleness, bruising, and unhealing ulsers due to chronic ischemia.

In the early stages Raynaud's disease, the treatment is pharmacologicaland conservative. Therapeutic approaches in conservative and pharmacological treatment resistant conditions include sympathetic nerve block, surgical sympathectomy, spinal cord stimulation, and recurrent amputations. Treatment in Burger's disease is smoking cessation, medical treatment, and by pass surgery in eligible patients. SCS is a good treatment option in patients with advanced stage disease where surgery is not appropriate, does not respond to medical treatment and sympathetic blocks.

SCS has been used since 1967 to treat various chronic pain syndromes such as failed back surgery syndrome, degenerative low back or leg pain, spinal stenosis, nerve root avulsion, complex regional pain syndrome, postherpetic neuralgia, neuropathic perineal pain, interstitial cystitis, urinary incontinence, refractory angina, and peripheral vascular diseases..$^{[7-9]}$
Patients with chronic limb ischemia are not suitable for endovascular intervention or surgery may be candidates for SCS treatment. In addition, patients who have undergone revascularization and cannot achieve pain control even after appropriate medical treatment may benefit from treatment with SCS.

The mechanism of action of SCS is unclear and several theories have been proposed.The electrodes in the epidural space stimulate myelin-free $c$ fibers and myelinated $A \delta$ fibers in the dorsal root ganglia. This leads to activation of cell signaling molecules such as extracellular signal regulated kinase (ERK) and protein kinase B (AKT). Activation of ERK and AKT transient receptor potential vanilloid 1 and depolarization of nerve terminals result in the release of vasodilators such as CGRP, which have potent microvascular vasodilatatory effects. The release of CGRP causes the release of endothelial nitric oxide (NO) and stimulates smooth muscle cell relaxation. These effects decrease vascular resistance and increase blood flow. In addition, SCS suppresses sympathetic vasoconstriction through inhibition of sympathetic nicotine transmission at the ganglion and postganglion level. Pain control or suppression of nociceptive transmission is achieved by the release of opioid peptides such as met-enkephalin. ${ }^{[10,11]}$

In this two cases report, we will emphasize the successful application of SCS in ischemic pain with persistent Raynaud's disease and advanced Burger's disease.

\section{Case 1}

A 55-year-old male patient who had followed up Cardiovascular Surgery clinic for 15 years with Buerger's disease. His left thumb amputated 10 years ago. He referred to our outpatient clinic due to painful necrotic ulcers on the thumb of the right foot.

On physical examination, distal peripheral pulses of the lower limbs were weak. The thumb of left foot had been amputated (Fig. 1a). There were necrotic ulcers on the thumb of the right foot and second finger. The right lower limb was hyperemic and the left lower extremity was cyanotic. The patient's pain occurs supine position and while he had resting, and he could sleep only by sitting. His pain was $9 / 10$ according to vizual analog scale (VAS) and according to Fontain classification he was accepted stage 4. 

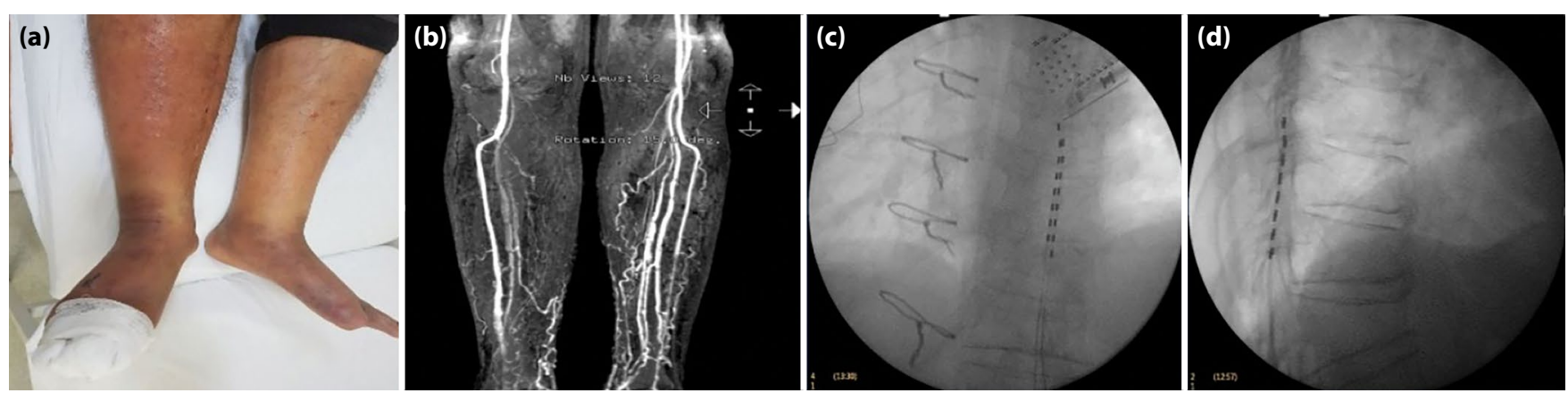

Figure 1. (a) Clinical findings of the patient: The thumb of the left foot had been amputated. There were necrotic ulcers on the thumb of the right foot and second finger. The right lower limb was hyperemic and the left lower extremity was cyanotic. (b) MRI angiography showed a severe obliterating arteriopathy of the right tibialis posterior and peroneal artery circulation on the right and collateral contrast material filling. (c) Posterior anterior (PA) images of fluoroscopy after SCS implantation: Positioning of two spinal cord stimulator leads over the dorsal horn column at T8-9 dorsal vertebra level. (d) Lateral images of fluoroscopy after SCS implantation: Positioning of two spinal cord stimulator leads over the dorsal horn column at T8-9 dorsal vertebra level.

MRI: Magnetic resonance imaging; SCS: Spinal cord stimulation.
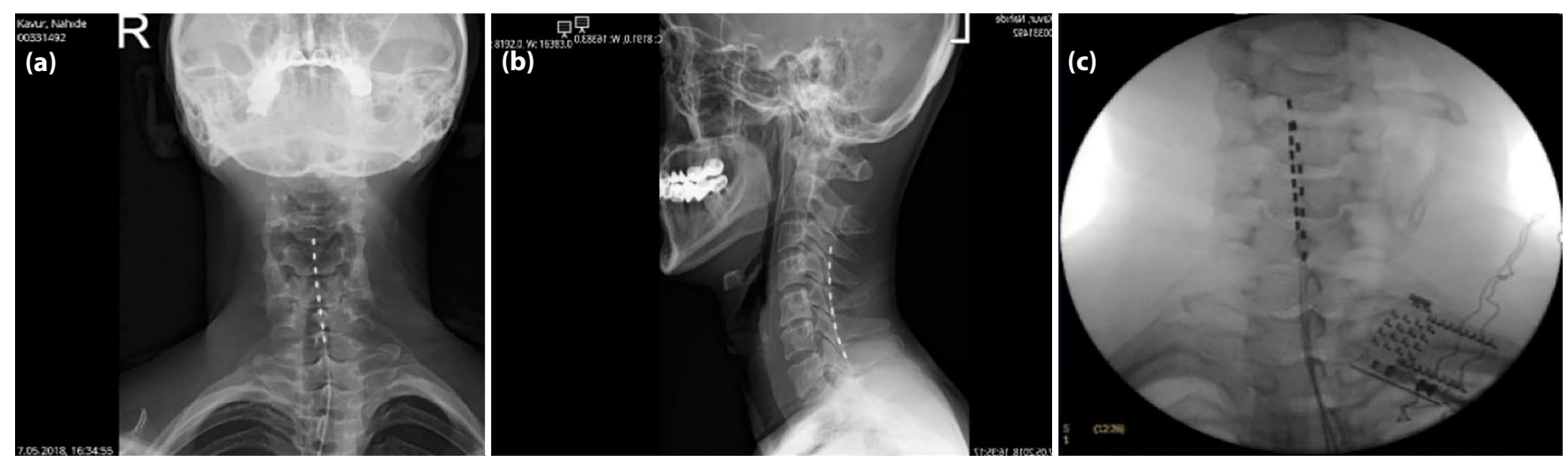

Figure 2. (a) Rigft SCS lead on the X-ray image at PA position. (b) Rigft SCS lead on the X-ray image at lateral position. (c) Right and left SCS leads on flouroscopy images at PA position.

SCS: Spinal cord stimulation; PA: Posterior anterior.

Angiography showed a severe obliterating arteriopathy of the right tibialis posterior and peroneal artery circulation (Fig. 1b).

Spinal cord stimulator was implated in the patient to provide permenant pain relief (Fig 1c, d).

In the early follow-up ( $2^{\text {nd }}$ week), VAS score was 4, walking time was $15 \mathrm{~min}$ (pre-operative: $5 \mathrm{~min}$ ), walking distance: $100 \mathrm{~m}$ (pre-operative: $60 \mathrm{~m}$ ), and sleep quality: $4 \mathrm{~h}$ (pre-operative: $2 \mathrm{~h}$ ) recorded. Due to infected ulcerative wounds, the patient was also followed by the wound care unit.

\section{Case 2}

A 35-year-old female patient who was followed with Raynaud's disease in cardiovascular surgery clinic for 2 years was admitted to our outpatient clinic with complaints of coldness, pallor, pain, and numbness in both of her hands. On examination, cyanotic discoloration, multiple ulcers, and dystrophic changes of the nails were detected. She had severe allodynia and hyperalgesia. Radial pulses were normally palpated. The patient followed up as Raynaud's disease with normal arterial angiography. She was recommended to quit smoking. The patient who did not respond to the medical treatment received 2 times diagnostic stellate ganglion blockage, 2 times neurolytic stellate ganglion blockage, and 2 times stellate ganglion radiofrequency thermocoagulation. Despite the interventional procedures, ulcerative lesions and pain control could not be achieved in the upper extremity. Cervical SCS was applied to the patient with the aim of permanent pain relief and ulser healing (Fig. 2a, b).

At the 6 months follow-up, the VAS score was 4 (preoperative: 9). Allodynia and hyperalgesia of the patient regressed. Digital ulcers showed a significant regression. Pallor and cyanosis in the extremities decreased significantly. During the 1-year follow-up, the patient presented with similar complaints in the left upper extremity and one more lead was implated on the left side (Fig. 2c). 


\section{Discussion}

Peripheral vascular diseases and Raynaud's phenomenon are common diseases and if not treated with a multidisciplinary approach, they cause serious problems such as disability due to limb loss and chronic pain affecting quality of life. The early treatment of Raynaud's disease is conservative, while Raynaud's syndrome is aimed at the treatment of the underlying disease and early stage peripheral vascular disease treated with pharmacologically. In advanced stage and conservative/medical treatment resistant cases, interventional and surgical treatment options are preferred for pain relief, ulcer healing, and reduction of amputation rates.

Patients with chronic limb ischemia that are not suitable for endovascular intervention or bypass surgery and those who cannot achieve pain control despite these procedures may be candidates for sympathectomy and SCS. Sympathectomy can be performed thermally, chemically, or surgically. Sympathectomy primarily has a vasodilatatory effect on the collateral circulation resulting from a reduced sympathetic tone.

Improved oxygenation of the tissues leads to less tissue damage, which results in decreased pain and increased healing of the ulcers. Pain reduction also occurs due to the interruption of sympathetic nociceptive interaction.

Randomized controlled trials that have no beneficial effects on sympathectomy pain relief, ${ }^{[12-14]}$ also there are studies showing that ulcer healing, pain relief, and major amputation rates decrease. ${ }^{[15-17]} \mathrm{Al}-$ though the effects of sympathectomy are not consistent, it is applied in selected cases, because there are studies reporting positive results on ulcer healing, pain regression, and amputation prevention. We applied recurrent thermal and chemical sympathetic ganglion block in our patient who was followed with medical treatment resistant Raynaud's disease. In our case, we used SCS successfully for permanent pain control and ulser healing.

The patients who are not suitable for endovascular interventions are followed by medical treatment consisting of analgesic, vasodilator, and anticoagulant drugs, while SCS is an effective alternative treatment for reducing refractory ischemic pain by improving microcircular blood flow in these patients. ${ }^{[18-24]}$ SCS provides pain reduction according to the gate control theory and modulating neurotransmitters released from the dorsal horn. ${ }^{[25]}$ The vasodilatory mechanism may be ascribed to the suppression of sympathetic vasoconstriction and the activation of vasodilatory molecules, thereby causing endothelial NO release and stimulating smooth muscle relaxation. ${ }^{[26,27]}$

Although its effects and efficacy are well known, there are a limited number of studies on the use of SCS in peripheral arterial disease. ${ }^{[20,28-32]}$ The current knowledge supports the use of this treatment in ischemic limb disease. There are not enough clinical studies related to use of SCS with Raynaud's disease and Burger's disease.

In a retrospective study of patients treated with SCS in Burger's disease, the positive effect of SCS on limb survival and development of new ulcers was discussed. ${ }^{[33]}$ There are also case reports of successful treatment of SCS in Burger's disease and Raynaud's disease. ${ }^{[34-37]}$

In the follow-up of treatment in critical ischemic disease, many examinations showing perfusion have been identified. In addition to ankle brachial index and transcutaneous oxygen tension, at previous studies MR angiography perfusion, technetium-99m-labeled Methoxyisobutyl isonitrilesingle-photon emission computed tomography (SPECT), and Thallium-201 (201T1)-SPECT were used to show microvasculer perfusion insufficiency in critical ischemic disease. ${ }^{[38-42]}$ And also, a recent study showed that lower-limb 201TI scintigraphy revealed that microcirculation intensity increased in the lower extremities of patients in the SCS treatment group after SCS implantation relative to that before SCS implantation. ${ }^{[43]}$ Thus, the efficacy of SCS and its positive effects on microvascular circulation were objectively tested by non-invasive advanced imaging techniques.

In this case report, we hope that the current data will be supported by future studies by emphasizing the positive effects of SCS on critical ischemic disease for pain relief, ulcer healing, and amputation delay when used in selected patients with Raynaud's disease and Burger's disease. 


\section{Conclusion}

Interventional methods are preferred in the treatment of advanced vascular disease and inoperable patients for revascularization to prevent amputation, pain relief, and ulcers. SCS provides pain management in selected cases with ischemic vascular disease that is resistant to conservative and minimally invasive pain treatment and is effective in reducing the amputation rate and ulcer healing.

Informed Consent: Written informed consent was obtained from the patient for the publication of the case report and the accompanying images.

Conflict-of-interest issues regarding the authorship or article: None declared.

\section{Peer-review: Externally peer-reviewed.}

\section{References}

1. Ubbink DT, Vermeulen H. Spinal cord stimulation for nonreconstructable chronic critical leg ischaemia. Cochrane Database Syst Rev 2005;CD004001. [CrossRef]

2. Block JA, Sequeira W. Raynaud's phenomenon. Lancet 2001;357:2042-8. [CrossRef]

3. Wigley FM. Clinical practice. Raynaud's phenomenon. $\mathrm{N}$ Engl J Med 2002;347:1001-8. [CrossRef]

4. Mills $J \mathrm{~L}$ Sr. Buerger's disease in the $21^{\text {st }}$ century: Diagnosis, clinical features, and therapy. Semin Vasc Surg 2003;16:179-89. [CrossRef]

5. Ting JC, Fukshansky M, Burton AW. Treatment of refractory ischemic pain from chemotherapy-induced Raynaud's syndrome with spinal cord stimulation. Pain Pract 2007;7:143-6. [CrossRef]

6. Cooke JP, Marshall JM. Mechanisms of Raynaud's disease. Vasc Med 2005;10:293-307. [CrossRef]

7. Costantini A. Spinal cord stimulation. Minerva Anestesiol 2005;71:471-4.

8. Wolff A, Vanduynhoven $E$, van Kleef M, Huygen F, Pope JE, Mekhail N. 21. Phantom pain. Pain Pract 2011;11:403-13.

9. Deer TR, Raso LJ. Spinal cord stimulation for refractory angina pectoris and peripheral vascular disease. Pain Physician 2006;9:347-52.

10. Pedrini L, Magnoni F. Spinal cord stimulation for lower limb ischemic pain treatment. Interact Cardiovasc Thorac Surg 2007;6:495-500. [CrossRef]

11. Brümmer U, Condini V, Cappelli P, Di Liberato L, Scesi M, Bonomini $M$, et al. Spinal cord stimulation in hemodialysis patients with critical lower-limb ischemia. Am J Kidney Dis 2006;47:842-7. [CrossRef]

12. Cross FW, Cotton LT. Chemical lumbar sympathectomy for ischemic rest pain. A randomized, prospective controlled clinical trial. Am J Surg 1985;150:341-5. [CrossRef]

13. Barnes RW, Baker WH, Shanik G, Maixner W, Hayes AC, Lin R, et al. Value of concomitant sympathectomy in aortoiliac re- construction. Results of a prospective, randomized study. Arch Surg 1977;112:1325-30. [CrossRef]

14. Fyfe T, Quin RO. Phenol sympathectomy in the treatment of intermittent claudication: A controlled clinical trail. $\mathrm{Br} \mathrm{J}$ Surg 1975;62:68-71. [CrossRef]

15. Repelaer van Driel OJ, van Bockel JH, van Schilfgaarde R. Lumbar sympathectomy for severe lower limb ischaemia: Results and analysis of factors influencing the outcome. J Cardiovasc Surg (Torino) 1988;29:310-4.

16. Keane FB. Phenol lumbar sympathectomy for severe arterial occlusive disease in the elderly. Br J Surg 1977;64:519-21.

17. Mashiah A, Soroker D, Pasik S, Mashiah T. Phenol lumbar sympathetic block in diabetic lower limb ischemia. J Cardiovasc Risk 1995;2:467-9. [CrossRef]

18. Eldabe S, Thomson S, Duarte R, Brookes M, deBelder M, Raphael J, et al. The effectiveness and cost-effectiveness of spinal cord stimulation for refractory angina (RASCAL Study): A pilot randomized controlled trial. Neuromodulation 2016;19:60-70. [CrossRef]

19. Tsigaridas N, Naka K, Tsapogas P, Pelechas E, Damigos D. Spinal cord stimulation in refractory angina. A systematic review of randomized controlled trials. Acta Cardiol 2015;70:233-43. [CrossRef]

20. Ubbink DT, Vermeulen H. Spinal cord stimulation for nonreconstructable chronic critical leg ischaemia. Cochrane Database Syst Rev 2013;2013:CD004001. [CrossRef]

21. Tshomba Y, Psacharopulo D, Frezza S, Marone EM, Astore D, Chiesa R. Predictors of improved quality of life and claudication in patients undergoing spinal cord stimulation for critical lower limb ischemia. Ann Vasc Surg 2014;28:628-32. [CrossRef]

22. Broggi G, Servello D, Franzini A, Giorgi C, Luccarelli $M$, Ruberti $U$, et al. Spinal cord stimulation for treatment of peripheral vascular disease. Appl Neurophysiol 1987;50:439-41. [CrossRef]

23. Augustinsson LE, Linderoth $B$, Mannheimer C, Eliasson T. Spinal cord stimulation in cardiovascular disease. Neurosurg Clin N Am 1995;6:157-65. [CrossRef]

24. Ghajar AW, Miles JB. The differential effect of the level of spinal cord stimulation on patients with advanced peripheral vascular disease in the lower limbs. $\mathrm{Br} J$ Neurosurg 1998;12:402-8. [CrossRef]

25. Guan Y. Spinal cord stimulation: Neurophysiological and neurochemical mechanisms of action. Curr Pain Headache Rep 2012;16:217-25. [CrossRef]

26. Tanaka S, Komori N, Barron KW, Chandler MJ, Linderoth B, Foreman RD. Mechanisms of sustained cutaneous vasodilation induced by spinal cord stimulation. Auton Neurosci 2004;114:55-60. [CrossRef]

27. Wu M, Linderoth $B$, Foreman RD. Putative mechanisms behind effects of spinal cord stimulation on vascular diseases: A review of experimental studies. Auton Neurosci 2008;138:9-23. [CrossRef]

28. Klomp HM, Steyerberg EW, Habbema JD, van Urk H; ESES study group. What is the evidence on efficacy of spinal cord stimulation in (subgroups of) patients with critical limb ischemia? Ann Vasc Surg 2009;23:355-63. [CrossRef] 
29. Simpson EL, Duenas A, Holmes MW, Papaioannou D, Chilcott J. Spinal cord stimulation for chronic pain of neuropathic or ischaemic origin: Systematic review and economic evaluation. Health Technol Assess 2009;13:1-154. [CrossRef]

30. Amann W, Berg P, Gersbach P, Gamain J, Raphael JH, Ubbink DT, et al. Spinal cord stimulation in the treatment of nonreconstructable stable critical leg ischaemia: results of the European Peripheral Vascular Disease Outcome Study (SCSEPOS). Eur J Vasc Endovasc Surg 2003;26:280-6. [CrossRef]

31. Augustinsson LE, Carlsson CA, Holm J, Jivegård L. Epidural electrical stimulation in severe limb ischemia. Pain relief, increased blood flow, and a possible limb-saving effect. Ann Surg 1985;202:104-10. [CrossRef]

32. Broseta J, Barberá J, de Vera JA, Barcia-Salorio JL, GarciaMarch G, González-Darder J, et al. Spinal cord stimulation in peripheral arterial disease. A cooperative study. J Neurosurg 1986;64:71-80. [CrossRef]

33. Donas KP, Schulte S, Ktenidis K, Horsch S. The role of epidural spinal cord stimulation in the treatment of Buerger's disease. J Vasc Surg 2005;41:830-6. [CrossRef]

34. Ryu SW, Jeon HJ, Cho SS, Choi RM, Yoon JS, Ko HS, er al. Treatment of digit ulcers in a patient with Buerger's disease by using cervical spinal cord stimulation -a case report-. Korean J Anesthesiol 2013;65:167-71. [CrossRef]

35. Pace AV, Saratzis N, Karokis D, Dalainas D, Kitas GD. Spinal cord stimulation in Buerger's disease. Ann Rheum Dis 2002;61:1114. [CrossRef]

36. Sibell DM, Colantonio AJ, Stacey BR. Successful use of spinal cord stimulation in the treatment of severe Raynaud's disease of the hands. Anesthesiology 2005;102:225-7.
37. Benyamin R, Kramer J, Vallejo R. A case of spinal cord stimulation in Raynaud's Phenomenon: Can subthreshold sensory stimulation have an effect? Pain Physician 2007;10:473-8. [CrossRef]

38. Duet M, Virally M, Bailliart O, Kevorkian JP, Kedra AW, Benelhadj S, et al. Whole-body (201)TI scintigraphy can detect exercise lower limb perfusion abnormalities in asymptomatic diabetic patients with normal Doppler pressure indices. Nucl Med Commun 2001;22:949-54. [CrossRef]

39. Cosson E, Paycha F, Tellier P, Sachs RN, Ramadan A, Paries J, et al. Lower-limb vascularization in diabetic patients. Assessment by thallium-201 scanning coupled with exercise myocardial scintigraphy. Diabetes Care 2001;24:870-4. [CrossRef]

40. Kuśmierek J, Dabrowski J, Bieńkiewicz M, Szumiński R, Płachcińska A. Radionuclide assessment of lower limb perfusion using $99 \mathrm{mTC}-\mathrm{MIBI}$ in early stages of atherosclerosis. Nucl Med Rev Cent East Eur 2006;9:18-23.

41. Liu JT, Chang CS, Su CH, Li CS. Insights into microcirculation underlying critical limb ischemia by single-photon emission computed tomography. medicine (Baltimore) 2015;94:e1075. [CrossRef]

42. Wright KL, Seiberlich N, Jesberger JA, Nakamoto DA, Muzic RF Jr, Griswold MA, et al. Simultaneous magnetic resonance angiography and perfusion (MRAP) measurement: Initial application in lower extremity skeletal muscle. J Magn Reson Imaging 2013;38:1237-44. [CrossRef]

43. Liu JT, Su CH, Chen SY, Liew SJ, Chang CS. Spinal cord stimulation improves the microvascular perfusion insufficiency caused by critical limb ischemia. Neuromodulation 2018;21:489-94. [CrossRef] 